\title{
Advancements of HIV/AIDS Treatment, Socio-Economic Impact, and the Impact of the HIV Co-infections
}

\section{Venkateswarlu Chamcha*}

Emory Vaccine Center, Yerkes National Primate Research Center, Emory University, Atlanta, Georgia 30329, USA

AIDS caused by HIV has been a significant global pandemic, which is continuously threatening with more than two million newer infections and more than one million deaths each year. Human interventions to prevent or to cure the disease have been paid off at large proportions, yet not to the extent of reducing or completely nullifying those two million newer infections each year. To prevent many novel vaccine approaches have been showing very significant success, but very slow to come in the pipeline process mainly due to theirs reduced efficacies at pre-clinical or clinical trials level. Recently it has been reported that cure from AIDS using a monoclonal antibody ( $\alpha 4 \beta 7)$ therapy along with ART has been highly successful in non-human primates. Taken together these novel advancements, I am very hopeful that the burden of AIDS pandemic may be reduced substantially in the coming days.

\section{In This Issue}

We are bringing some interesting reports on the advancements of HIV/AIDS treatment, socio-economic impact, and the impact of the HIV co-infections [1,2]. First and foremost, we are bringing the report of the clinical outcome of ART on HIV infected patients in Nairobi
Kenya followed by EBV-associated tumors in HIV infected patients [3]. We also covered the reports of association between genetic divergence and HIV resistance and finally reported the ways on scaling up the strategies for preventing HIV infections [4]. Hence, I believe strongly that the current issue of J AIDS \& Clinical Research attracts wide range of readership.

\section{References}

1. Dalmida SG, Hunte-Ceasar T, Martinez GCB, Schweizer A, Freeman B, et al. (2016) Examination of HIV risk and the HIVIAIDS epidemic in the U.S. Virgin Islands. J AIDS Clin Res 7: 621.

2. Khaba MC, Ramdial PK, Pillay B, Steyn AJ, Nargan K (2016) Epstein-Barr virus-associated myoid tumors in human immunodeficiency virus-infected patients. J AIDS Clin Res 7: 616.

3. Ngayo MO, Okalebo FA, Bulimo WD, Mwachari C, Guantai AN, et al. (2016) Impact of first line antiretroviral therapy on clinical outcomes among HIV-1 infected adults attending one of the largest hiv care and treatment program in Nairobi Kenya. J AIDS Clin Res 7: 615.

4. Vubil A, Jani VI, Mabunda N, Ismael N, Ramalho D, et al. (2016) Genetic diversity and transmitted drug resistance of HIV-1 subtypes in blood donors candidates in Northern Mozambique. J AIDS Clin Res 7: 623.
*Corresponding author: Dr. Venkateswarlu Chamcha, Ph.D., Department of Microbiology and Immunology, Emory Vaccine Center, Yerkes National Primate Research Center, Emory University, Atlanta, Georgia 30329, USA, Tel: 404727 1432; Fax: 404727 7768; E-mail: vchamch@emory.edu

Received November 14, 2016; Accepted November 15, 2016; Published November 19, 2016

Citation: Chamcha V (2016) Advancements of HIVIAIDS Treatment, SocioEconomic Impact, and the Impact of the HIV Co-infections. J AIDS Clin Res 7: e124. doi:10.4172/2155-6113.1000e124

Copyright: @ 2016 Chamcha V. This is an open-access article distributed under the terms of the Creative Commons Attribution License, which permits unrestricted use, distribution, and reproduction in any medium, provided the original author and source are credited. 